\title{
Civil-Military Relations and the Construction of Consoli- dated Democracy: The Case of Bulgaria
}

\author{
Colonel Valeri Ratchev and Dr. Velichka Milina
}

The past ten years have been witness to a remarkable set of achievements in Bulgaria: the basic goals of post-totalitarian transition in civil-military relations have been broadly attained; a parliamentary democratic regime is functioning steadily; civil society is being structured on an institutional level; the principles of a market economy are establishing themselves; the process of change of ownership has almost been completed; the foundations of civil control over the military have been laid; and the armed forces are politically neutral, obeying solely the legitimately elected political institutions and the laws which result from that process. However, much work remains to be done. Consolidating the process of democratization poses many questions. What paradigm of civil-military relations will prove sustainable for Bulgaria? Which form of control over the armed forces would be most appropriate for the development of society within the newly constituted state? And what are the problems caused by the details of societal transformation? In this paper, we argue that, with large changes taking place within the functioning of the state, it is necessary to purposefully introduce norms and practices of the model of shared responsibility into the overall context of civil-military relations.

After 1989, the military and civil spheres found themselves in the unique situation of taking part in the total transformation of Bulgarian society. All three parties to civil-military relations (the political elite, the military professionals, and the citizens) have been adopting new cultural models of behavior and relations. Political institutions, ideas about their ideal functions, and visions of the relations among them-all have been changing. The role, organizational structure, competencies, political leadership, and means of control over the armed forces are in transition. The essential relations between the citizens and the state have been altered. ${ }^{1}$ None of this has been easy. The complexity of the situation is emphasized by the comparative lack of any practical or theoretical models of such largescale transformations. The aim, obviously, is to fully replace totalitarian political control of the military by the party/state with sustainable principles and mechanisms that lead to democratic and objective controls over the armed forces, after the classical scheme suggested by Samuel Huntington. The desired result is primacy on the part of the civil and political spheres over the previously and largely

\footnotetext{
${ }^{1}$ According to our experts and foreign observers, the legal basis regulating the relations between political society and the military sphere is considerably developed. Already adopted are a new constitution, a Law on Defence and Armed Forces, individual laws, and regulatory acts for some of the structures in the composition of the armed forces. These constitute a stable foundation for the institutionalization of civilian control.
} 
autonomous professional military sphere. The political power between them has been distributed in such a way that the military has become politically neutral, but, at the same time, the "professionalized officers are ready to meet the wishes of each social group that secures lawful power within the State." The outcome should lead to an increase in the status of the armed forces and an enhancement of their value to the nation-state.

The essential problem of civil-military relations is clear enough: one of society's institutions, the armed forces, is given a monopoly on the use of a large range of instruments of lethal force in order to protect the interests, external and internal, of that society. The problem which arises during a transition of power is that this monopoly on force endows the armed forces with at least the potentialthough not necessarily the inclination-to dominate all other institutions. To dominate does not necessarily mean implementing a military dictatorship; that is a frightening extreme, and one completely inconsistent with the notion of liberal democracy. But being dominant could also mean having undue influence in domestic, economic, and international state and public affairs. In cases where it can be said that a domestic political issue was decided in a particular way because of something the military either did or did not do, then it could be concluded that the military has exercised influence in that society. However, motives need to be looked at carefully. One specific aspect of this need to examine motives behind actions can be seen not only in Bulgaria, but also within other countries in which defense reform has taken the form of downsizing of personnel and arms. The potential for "soft" military intervention does not necessarily derive from a hunger for power. Instead, it can be attributed to some of the highest ideals inherent in the military profession: to provide stability where political institutions are weak or immature; to save a nation from itself; to overcome political deadlock; to prevent chaos; to continue provision of essential services in the face of social disruption; and so on. ${ }^{3}$ To analyze the actual contemporary state of civil-military relations in Bulgaria, we divide such relations into two levels. The first covers the legitimization and institutionalization of civilian control, and includes the laws, ordinances, and regulatory acts adopted in the areas of defense and the armed forces, together with the organizational structures and control mechanisms built. The second is socio-cultural, and is determined mostly by the political culture of the three elements of civil-military relations: the political elite, the military profession, and the citizenry.

In the last decade, Bulgaria has traveled the path of democratizing civilmilitary relations in company with other Eastern European countries. Depoliticization of the troops has been carried out; a civil and political governing body

\footnotetext{
${ }^{2}$ Samuel Huntington, Soldier and the State: Theory and Policy of Civil-Military Relations (Sofia, 1998), 85.

${ }^{3}$ The current example of Pakistan is instructive.
} 
of the Ministry of Defense has been established. A new social status for the military, adequate to both the specificity of their labor and the principles of building a democratic society, has evolved. These ambitions regarding democratic development are consistently paralleled by aspirations to European Union (EU) membership, by the practices within the Partnership for Peace, and by the intention to join the North Atlantic Treaty Organization (NATO). Undoubtedly, the criteria for membership of NATO and the EU have important organizing, directing, and stimulating roles in the development of policies for establishing democratic control over the military.

The existence of modern laws and democratic institutions, however, is only a prerequisite for effective civilian control. If such control is to be fully realized, much depends on the maturity of the political culture, of politicians, and of society itself. It is not an accident that the specialized literature of the last several years emphasizes the pervasive cultural dimensions of the problems of democratic transition. It becomes increasingly obvious that the borrowing of law, of adapting institutions, and applying external rules for civil-military connections from countries with developed democratic cultures does not lead to an automatic restructuring in values, psychological attitudes, and political behavior in post-totalitarian societies.

The reason why this is so often the case lies in the specific features of the prevailing political culture in question and in the conditions which have an impact on its functioning.

- The political culture characterizes the qualitative level at which political relations function. It includes political knowledge and values, plus the sustainable patterns of political behavior. One of the "objective laws" to which its action is subject is that of inertial cultural effect. This law suggests that each political generation inherits from the preceding one a certain volume of knowledge, values, and behavior patterns. A period of transition will tend to see the endurance of values and behavior patterns in civil-military relations that are typical of totalitarian society: the mono-logical nature of communication, the persistence of ideological fears, the tendency to place group (social, corporate, or political) interests above the national ones, etc.

- Cultural determinism (this law by another name) lays stress on the roles of tradition and ethno-psychological features for the functioning of sustainable patterns of political behavior. For Bulgarians, to neglect the essentially nihilistic attitudes toward institutions, politicians, and law that are traditional for the Bulgarian at the level of daily awareness would render any transitional efforts senseless. At the same time, the positive attitudes and traditions that ensure the high prestige of the Bulgarian armed forces could contribute to a relatively painless restructuring of relations between the civil and the military spheres. Since the end of the nineteenth century, 
the Army has arguably been a profoundly attractive institution for the most sincere patriots, a group that might be described as those seen as the most worthy Bulgarian men. The prestige of the military came above all from their contribution to the attainment of national goals under various historical conditions. In Bulgarian society, the conviction is held that, whether or not national goals have been achieved, the military have always performed their duty.

Under the conditions of post-First World War party pluralism and wide public debate, the problems of the military were a subject of attention and concern for all governments until 1945. Military budgets were discussed publicly, and approved by the National Assembly. Society was well informed of the problems of the military and responded to their needs, notwithstanding that in some periods the military budget exceeded thirty percent of the state's expenditures. The officer cadre became one of the most prestigious groups in the hierarchy of government officials.

In the post-Cold War years of transition to democracy, the military has been one of the most important factors supporting reform. Without directly interfering, they have created stability at critical political moments. In the last decade, the troops have not ranked lower than second place in the hierarchy of public confidence and support. These facts are an important element of the context of civil-military relations. The Bulgarian experience confirms that it makes no difference for democratic controls over the military how good the written laws are. In the long run, their effectiveness is determined by the mechanisms and practices of their application. Laws need to be in conformity with the specific characteristics of the national political system and culture; they have to be based on mutually-understood common goals, shared confidence, and partnership between the military and the civilians, between the Army and society.

In addition to the arena of political culture, another important factor for ensuring harmonious civil-military relations at the end of the transition period is the revival of civil society, the reinvigoration of the process of actively "becoming" a citizen, whose most important feature is the activist culture. This is a process whose results affect all three components of the civil-military relationship. The spectrum contains politician-citizens, soldier-citizens, and a society composed of independent citizens. Ralf Dahrendorf argues that the transformation of the totalitarian subject into a citizen takes approximately sixty years, ${ }^{4}$ an estimate that considerably slows expectations for the emergence of a mature civil society, but sounds realistic. Because of the action of the inertial cultural effect, the Stakhanov approach is impossible. Attempts at skipping whole cultural periods of development have usually been unsuccessful, as can be seen in Mongolia and some Soviet republics. The presumption to attain within ten to fifteen years what has taken

\footnotetext{
${ }^{4}$ Ralf Dahrendorf, Reflections on Revolution in Europe (Sofia, 1992), 87-92
} 
other nations centuries has proved its absurdity. The reason for this failure lies in the specificity of culture, understood as the quality of human activities in a given place. A political culture can develop only as a virtually functioning one. In other words, the transformation of all participants in civil-military relations into citizens supposes their collective participation in a real political experience through the application of behavior patterns typical of democratic political culture. In this sense, it should not be thought that, until the formation of the citizen and the civil society is completed, the application of practices and patterns characteristic of the developed democratic societies can not start. The process here is an interactive one; a political culture "learns by doing." About ten years after the beginning of the posttotalitarian transition and the establishment of a democratic political system, the gradual introduction of management patterns and mechanisms of relations typical of a developed consolidated democracy can and will develop. The fact that a considerable period will be needed for the consolidation of these developments is a separate issue.

The control of the democratic political society over the military sphere, as a pattern of relations in the period of transition, was an absolutely necessary stage. The overcoming of the totalitarian mechanism of party control necessarily presupposed the establishment of "objective control" over the armed forces. The democratic state had to recognize, legalize, and control its monopoly on violence. The first stage of democratization was more or less characterized by the unsystematic introduction of Western patterns of democratic control over the military, combined with the efforts of politicians, scholars, and the military to find the best formula. To that end, under the Law on Defense and Armed Forces of the Republic of Bulgaria, regular servicemen are prohibited from being members of political parties, movements, and coalitions with political objectives, as well as from participating in activities that would otherwise violate their political neutrality, for the whole term of their military service. This is a pattern of depoliticization that substantially differs, for example, from the German "Inner Führung," although the principle is similar.

The Bulgarian Ministry of Defense employs more civilians than do the comparable ministries in several NATO states. As early as 1991, a civilian minister assumed the political functions of administration. Since then, his activity has been supported by a political cabinet, and by civil directorates that also perform activities for the administrative service of citizens and legal entities. Military officers also serve in these "civil directorates," when the nature of the activity requires military expertise. A key point in the democratization process is the moment when the civil political governing body assumes responsibility for the formulation of a national security strategy and a national military doctrine. These formulations set the context and framework for the armed forces (including peacetime and wartime strengths, organizational and functional structure), and for their provision with resources. The fact of "assuming responsibility" is of central importance for the 
success of democratic control, as it forces the politicians to educate themselves in matters relating to defense and the armed forces.

As in all democracies, the discussion of the defense budget within Government and Parliament is not only a question of figures. It is also about what specific results must be attained with the intended defense budget, what the program is for long-term investment in the armed forces, and what the social cost is for of a specific budget item. Moreover, this practice turns the debate on defense and the armed forces into a social phenomenon. There is no political force and social stratum that is not participating, in one way or another, in the solution of the problems of military reform, such as closing garrisons and bases; the use of training ranges in close proximity to settled areas; deciding the fate of the huge numbers of accumulated weapons from the time of the Warsaw Pact; and determining relations with NATO during the Kosovo crisis and during the debate on NATO membership. Last but not least, the assumption of responsibilities by civilians has freed the military from the heavy necessity of making political, social, and economic decisions about the defense and military capabilities of the country. Their expertise is used in the making of all political decisions on defense and armed forces, but the responsibility for making decisions lies with civilians. For the military, there remain the important responsibilities for operational planning, training and preparation of forces, and the maintenance of reserve forces.

Another positive sign of the democratization of civil-military relations is the practice introduced several years ago whereby the executive power reports to the Parliament, and through this to society as a whole, on the implementation of programs for national security and defense. The preparation and publicationincluding on the Internet - of the annual reports on national security, and on the defense and armed forces, is already both a legal and moral obligation of the political body governing defense matters. This practice has two main results. For the first time, viewpoints on the relationship between stated political objectives and priorities in the sphere of security and defense, programs and policies for their attainment, information on the state of security institutions (including structure, strength, and equipment), and an explanation of the way in which resources are allocated are submitted to the populace. For that purpose, horizontal interaction among the various institutions has been realized, and in the interests of public awareness the typical privacy of the "power" departments has been constitutionally limited. The result is transparency of the guiding assumptions of the state and the attitude towards them of the big political forces, so that civil society can compare, control and, in the long run, correct the course of government.

The next and equally necessary stage, however, that civil-military relations face is related to the challenges of consolidating democracy in Bulgaria. In this sense, Bulgarian society will have to move further toward the values and relations of a fully mature democracy, which, in the sphere of civil-military relations, means the values and patterns of relations of shared responsibility. A consoli- 
dated democracy is a political system under which democracy, in its capacity as a complex system of institutions, rules, and stereotyped behavior patterns, has been accepted, in preference to any undemocratic alternative, by the parties to political relations and by the citizens. It can be defined using three parameters: behavior, attitude, and constitutionality. ${ }^{5}$ From the point of view of behavior, the democratic regime in a given territory is consolidated if no significant national, social, economic, political, or institutional forces attract considerable resources for attaining their objectives by creating an undemocratic regime or forcible detachment from the state. According to attitude, the democratic regime is a consolidated one when a considerable part of the society, even in the face of large-scale economic problems and deep disappointment with the government, continues to think that the democratic procedures and institutions are the most suitable method of government. In terms of constitution, a democratic regime is a consolidated one when the governmental and non-governmental forces have to the same extent accepted the fact that conflicts are to be solved within the framework of the nation's laws, procedures, and institutions.

There exists no single type of consolidated democracy. It may develop and improve its quality by enhancing the minimum economic level accessible to all citizens and by expanding the participation of people in the political and public life of the country. Within the framework of the category "consolidated democracy" there exists a process of development, from a democracy with low-quality parameters to a democracy with high-quality ones. To Bulgarian society, however, which is only at the beginning of the process of consolidation of democracy, it is important that the specific conditions and requirements for its success be clearly understood. The necessary conditions that have to be present, or need to be created, to consolidate democracy are: an independent and viable civil society; a political society and culture which respects government procedures; a constitutional consensus that the democratic state embodies the rule of law; and a public administration system capable of being used by, and accountable to, democratic society. In short, this is a system of socially and politically elaborated norms, institutions, and rules that is constitutionally placed between the state and the market. It is especially important to note that a consolidated democracy is a phenomenon that encompasses more than the particulars of a political regime, which is merely a pattern of organization. It is an interactive system, and no sphere therein can function optimally and effectively without definite support from another sphere or, very often, from all the remaining ones. It follows that a precondition for the consolidation of democracy is the acceptance of constitutional liberalism. It represents a system of rights and freedoms of the citizens, protected by the state, the

\footnotetext{
${ }^{5}$ J. Linz, and A. Stefan, “Toward Consolidated Democracies," Journal of Democracy (Apr. 1996) 14-33.
} 
rule of law, and a separation of powers. For over a century, the Western liberal democracies have combined democratic politics with constitutional liberalism.

Today, 118 out of 193 countries in the world are democracies. The greater part of the world population lives in them: $54.8 \%$. In many states with young democracies, free elections are held, but power is wielded in an authoritarian way and basic human rights are violated. This is the so-called situation of "illiberal democracy"- a regime under which there is detachment of democracy (elections) from constitutional liberalism. The opposite variant is also possible-liberal autocracy. Under this political arrangement, the principles of constitutional liberalism are applied but democratic election procedures are neglected. ${ }^{6}$ Consolidated democracy may develop only in the presence of constitutional liberalism. The experience gained from post-totalitarian transitions shows that the countries of Central Europe move more easily from communism to liberal democracy where they have experienced a phase of liberalism without democracy (those with historical memories of the Austro-Hungarian Empire, for example, are familiar with a classic liberal autocracy). The other states, after the establishment of a democratic political regime, face the serious problems of the transformation of the principles of constitutional liberalism into a pattern of cultural behavior. The lack of a liberal tradition in this respect is a reason for the phenomenon often found in new democracies, where a democratically-elected executive power (Government, President) decides that they possess absolute sovereignty, that the confidence of their electors allows them to centralize power and constantly interfere with the powers and rights of other institutions of state authority and with the activities of the "third sector" (private business).

For civil-military relations in the transitional, post-totalitarian phase, a principal problem is defining the competencies of the various elements within the civil-military relationship, setting out the context for their interdependence, and creating the conditions that will ensure the autonomy of the professional military sphere. This requires establishing a recognized pattern of shared responsibility. This sharing is the main meaning and purpose of the political and constitutional consensus. By definition, consensus is not merely consent, but shared consent. The possible commonalities, or the basis for reaching a consensus, include values, rules of relations, and practical policy. In keeping with these, there are three possible levels of shared consent and responsibility in civil-military relations.

Fundamental consensus is the level at which agreement with respect to common values of the highest order is reached. In the case of civil-military relations, this may be security of the state, society, and individuals, the national interest and national goals, democracy, rule of law, constitutionalism, etc.

Functional (procedural) consensus is the level of consent regarding "the rules of the game" and the norms according to which civil-military relations will func-

\footnotetext{
${ }^{6}$ Z. Fareed, “The Rise of Illiberal Democracy,” Foreign Affairs (Nov./Dec. 1997)..
} 
tion. These rules are fixed in democratically passed laws, and their observance ensures maximum participation by civil society and maximum military professionalism. For the pattern of shared responsibility, the underlying rules of relations between the civil and the military spheres are that the civil (political) governing body defines the political-strategic objectives of national defense and the tasks of the armed forces, while also providing the resources for these objectives to be carried out; the military, for its part, commands and develops the armed forces in order to carry out the tasks and attain the objectives set by the civil sphere. Civil society controls the military sphere by means of the institutions of political power and organizations of the business sector. The military, as professionals and experts, exercise politically-neutral control over strategic, technical, and operational matters.

Political consensus is the level of shared and practical civil-military decisionmaking. The main issue in such decision-making is the successful implementation of military reform. It is a crucial element of civil-military relations, of the political governance of defense, and of democratic control over the activity of both the politicians and the military. Everything here has the potential to become extreme: the strategic culture of Bulgarian politicians and the military can change radically; public perceptions and the paradigm of national security, as well as the role of the troops needed for its guarantee, can alter; the fate of scores of thousands of people, their cities, and even entire regions can be affected by policy preferences. Out of these uncertainties can come complex and ambiguous political and popular attitudes toward the specific politicians and military staff involved in either promoting or opposing the reforms, as well as toward the corporate thinking of the political and military elites. The relations between these groups can affect the officer corps as a whole, creating what might be an extreme test of the emerging reformed system. These things need to be avoided.

As experts note, the attainment of government consensus means stability for the defense system, confidence within the governing staff, positive motivation of officers, and the application of military professionalism. In short, the success of the military reform program means success for the new pattern of the civil-military relations.

The pattern of shared responsibility (consensus) also presupposes a new understanding of the role of conflict in the sphere of the civil-military relations. Shared consent will not always mean unanimity. There are, however, some obligatory "rules" that have to be followed to remain within the cultural pattern of shared responsibility. First, conflicts (dissent) are allowed only at the level of government (political) consensus. The conflict at the level of values, of the "rules of the game," means dissent from the consensus pattern of shared responsibility. Conflicts and

\footnotetext{
${ }^{7}$ V. Ratchev, "Effective Defence Management and Civil-Military Relations," Military Journal 6 (2000), 54
} 
differences of position at the level of the practical policy of governance of civilmilitary relations are not only allowed but are even desired. Through them, the discovery of more adequate, optimum, and efficient government decisions is fostered. Second, an emerged conflict will be solved according to the rules of the game, through the legal mechanisms governing civil-military relations, adopted by consensus of the constituent subjects. Solving a conflict in this way leads to consent at a higher level, at a new level of balance of the interests between politicians, the military, and society. The application of the principles of consensus is also the way to overcome the unique situation caused by the fact that the military must have an organization separate from the society, with its own structure, culture, and ethics, in order to carry out their tasks for defense of society while, at the same time, ensuring that this military culture corresponds to and protects the civil norms and values of society.

At this level of consensus, one may speak about distributed responsibility. The distribution of responsibility is in fact the methodology for civil-military relations when defining and implementing defense policy. Two issues remain to be resolved here. One is related to specifying the term "military professionalism." There exists a need for a Bulgarian debate on this to ensure a fuller understanding of the role of the military and the most appropriate outcome within the military reform program. Education is the other significant issue, and it has two aspects. The first is related to the development of a system, adequate to the nation's needs, for intensive education of civil staff about all fields of defense. The experience of civilian control in the post-totalitarian period shows that it does not especially matter how good the laws and rules regulating the political government and the civil control of military activity are if there are not enough civilians who are trained to speak with the military in a common language on professional matters. The second aspect relates to the reform of military education. This is of exceptional priority in the context of military reform, preparation for NATO membership, and the attainment of efficiency in civil-military relations. The aim is to create conditions for and then to implement a radical change in the strategic culture and mentality of the military and in their training to work effectively under a democratically accountable civilian governing body.

This pattern of shared responsibility is indicative of the advance of civil society, of military professionalism, and of the maturity of the democratic political culture. But the changes in the pattern of civil-military relations are determined not only by the new domestic environment, but also by the sweeping changes in the international environment. These cannot be fully discussed here but, on their own, they have made the dividing line between civilians and the military thinner. The threat of a large-scale war has faded into the background, to be replaced

\footnotetext{
${ }^{8}$ Ibid.
} 
by new, largely non-military aspects of security. ${ }^{9}$ The people living within one state or civil society are sharing to an increasing extent common space with the rest of the people in the world. The shared risk factors-environmental pollution, refugee flows, humanitarian crises, and the rest—become increasingly more global, meaning that no state can avoid them nor is capable of coping with them alone. Consequently, by trying to solve the problems of common risk, states have to reconsider how to best use their armed forces for political, economic, environmental, and other means. The reconsideration of the notion of security supposes a new approach to problems; the only reasonable certainty is that the future is unlikely to warrant a return to the narrow military approach characteristic of the Cold War. This process of globalization contributes directly to a new world order. As a result, security and defense policy is formed by increasing numbers of interested parties-not only states, but also multinational corporations, pressure groups, non-governmental organizations, and mass media—each of them possessing a certain capacity for global influence and action.

These changes give rise to new concepts of national security. They question the role of the armed forces as the only or best means of protection in situations where the state may be seeking ways to ensure security for their citizens against economic development problems, health care difficulties, environmental threats, etc. This confronts the armed forces with questions relating to their legitimacy in the eyes of the society. This is not surprising. The main difficulty for the armed forces is that the changes in the external strategic situation and the domestic environment are taking place simultaneously instead of consecutively. While the armed forces are subject to reductions and restructuring, they are being required to carry out an increasingly wider range of tasks, including participation in peace support operations as well as traditional operations. That is why the politicians require from them more flexibility, a requirement that is itself indicative of the need to change to the new pattern of civil-military relations outlined above. If Bulgaria wants to participate in the international security system, it should immediately proceed to the gradual application of the pattern of shared responsibility between politicians, the military, and society advocated in this article. This ought to be the national Bulgarian security goal, formulated within a developing consolidated democracy. It is hard to see how integration within NATO and/or the EU will be possible in the absence of these conditions.

\footnotetext{
${ }^{9}$ The Military and the Society in Western and Eastern Europe. Comparative Study, (Moscow, 2000), 21-41 (in Russian).
} 


\section{Bibliography}

Dahrendorf, Ralf. Reflections on Revolution in Europe., 1992.

Fareed, Z.. "The Rise of Illiberal Democracy." Foreign Affairs (1997): 14-33.

Huntington, Samuel P.. The Soldier and the State: The Theory and Politics of CivilMilitary Relations. Cambridge, MA: Harvard University Press, 1985.

Linz, Juan J., and Alfred Stepan. "Toward Consolidated Democracy." Journal of Democracy (1996).

Ratchev, Valeri. Effective Defence Policy through Integrated Management, Transparency, and Accountability In Integrity in Defence: Effective, Transparent and Accountable Management. Sofia: Euro-Atlantic Education Initiative, 2009. 